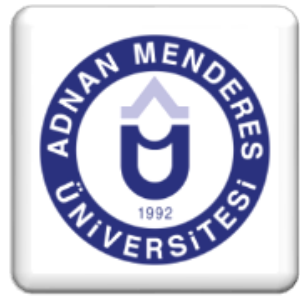

\section{Ortaöğretim Matematik Programının Hedeflediği Matematiksel Yeterlilik ve Becerilerinin Kazandırılma Sürecinin Öğretmen Görüşleri Temelinde İncelenmesi $^{1}$}

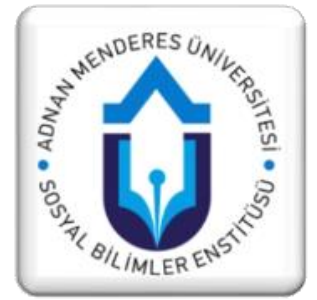

\title{
ÖZET
}

Bu nitel çalışmayla, Ortaöğretim Matematik Dersi Öğretim Programı' nın öğrencilere kazandırmayı hedeflediği matematiksel yeterlilik ve becerilere ilișkin öğretmen görüşleri belirlenmeye çalıșılmıștır. Araștırma 2015-2016 eğitim öğretim yılı bahar döneminde, Aydın ili ortaöğretim kurumlarında görev yapan 5 kadın 10 erkek olmak üzere toplam 15 matematik öğretmeni ile yürütülmüştür. Araştırmaya ilişkin verilerin toplanmasında, 14 sorudan oluşan yarı yapılandırılmış görüş̧me formu kullanılmış ve elde edilen veriler betimsel analiz yöntemine uygun olarak çözümlenmiştir. Araştırmanın sonucunda, programın öğrencilere kazandırmayı hedeflediği matematiksel yeterlilik ve becerilere ilişkin olarak hali hazırda uygulanan sinav sisteminin, mevcut öğretim programını yetiştirme zorunluluğunun ve öğrencilerin hazırbulunuşluk seviyelerinin uygun olmamasının en büyük sıkıntıların başında geldiği sonucuna ulaşılmışıı. Öğrencilere kazandırılması hedeflenen bu becerilerin etkili öğretimine yönelik hizmet-içi eğitimin verilmesi önerilebilir.

Anahtar Sözcükler: Ortaöğretim Matematik Programı, Matematiksel yeterlilik, Matematiksel beceri, Öğretmen görüşleri.

\section{The Examination of Teacher Opinions on Mathematical Competence and Skills of Secondary Mathematics Curriculum}

\begin{abstract}
The aim of this qualitative research is to determine the teachers' views with regard to mathematical qualifications and skills that the mathematics curriculum at secondary education -aimings to provide the students with. This research was conducted at the spring term of 2015-2016 academic year with 15 mathematics teachers including 5 female and 10 male teachers who work in secondary schools in Aydin. In data gathering, semi-structured interview form with 14 questions was used and the data obtained was analyzed in conformity with descriptive analysis method. As a result of this research, it was concluded that the currently applied exam system, the obligation to keep up with the current curriculum and the readiness level of students' which is not at required level are the leading problems with regard to mathematical sufficiency and skills that the curriculum of mathematics at secondary education aims to provide the students with. It might be suggested that in service training might be given to the teachers to teach these target skills effectively to the students
\end{abstract}

Key words: Mathematics, Curriculum of Secondary Education, Mathematical Sufficiency, Mathematical Skills, Teacher views.

\footnotetext{
${ }^{1}$ Bu çalışma, 13-15 Ekim 2016 tarihlerinde Rize, Recep Tayyip Erdoğan Üniversitesi’nde düzenlenen VI. Uluslararası Eğitimde Araştırmalar Kongresi, "Eğitimde Kalite Güvencesi: Politikalar \& Yaklaşımlar" adlı kongrede sözlü bildiri olarak sunulmuştur.

${ }^{2}$ Milli Eğitim Bakanlığı, Matematik Öğretmeni.

${ }^{3}$ Doç.Dr., Adnan Menderes Üniversitesi, Eğitim Fakültesi, Eğitim Bilimleri Bölümü.
} 


\section{Giriş}

Günümüzde bilim ve teknolojinin hızla gelişmesiyle birlikte kültürel, siyasal, ekonomi ve eğitim gibi birçok alanda beklentiler değişim göstermektedir. Özellikle eğitim dünyasında bu gelişmelerin paralelinde ciddi değişimler yaşanmış, bireylerin nasıl öğrendiğiyle ilgili önemli bilgilere ulaşılmış ve birçok yeni yaklaşım geliştirilerek toplumun beklentilerine cevap verilmeye çalışılmıştır (Doruk, 2010). Bu bağlamda eğitimin amacı devamlı öğrenen, öğrendiklerini uygulayabilen, eleştirel düşünme ve problem çözme yeteneğine sahip olan, yeni fikirler geliștirebilen, çözüm üreten ve yeniliklere ayak uydurabilen insanlar yetiştirmektir (Olkun ve Toluk, 2003). Matematik eğitimi açısından bakıldığında ise matematik eğitimcilerinden, gerçek problem durumlarında etkili çözümler üretebilen, günlük yaşamıyla öğrendiği matematik bilgilerini bağdaştırabilen, matematiğin ve gerçek dünyanın iç içe olduğunun farkında olan ve bunların sonucunda matematikten zevk alan ve korkmayan bireyler yetiştirmesi beklenmektedir (Çiltaş ve Yılmaz, 2013). Matematik toplumun gereksinimleri doğrultusunda sayma ve ölçme ile ortaya çıkmış, günümüzde ise özellikle teknolojide sıklıkla kullanılmasıyla birlikte diğer bilimler arasında önemli bir yere kavuşmuştur (Çiltaş, 2011). Altun (2002)' a göre matematik öğretiminin amacı, 'kişiye günlük yaşamın gerektirdiği matematik bilgi ve becerileri kazandırmak, ona problem çözmeyi öğretmek ve olayları problem çözme yaklaşımı içinde ele alan bir düşünme biçimi kazandırmak" tır.

\subsection{Matematiksel Yeterlilik}

Bir bireyin öğrenim hayatı boyunca matematikte başarı gösterebilmesi, öğrendiği bilgilerin ona anlamlı gelmesine bağlıdır. Günlük hayatta, okulda ya da matematik dersinde karşılaşılan problemleri matematiksel mantık yürüterek çözebilmek, matematiksel yeterliliğe sahip olmayı gerektirir. Matematiksel düşünmenin öğrenilmesi ve bu düşüncenin günlük hayata aktarılabilmesi, matematiksel yeterliliğin oluşabilmesi için gereklidir (Acar, 2013). Kilpatrick, Swafford ve Findell (2001, s.8), "Bir kimsenin başarılı bir şekilde matematik öğrenmesi" ifadesinin karşılığını "matematiksel yeterlilik" terimi ile açıklamışlardır. Ayrıca bu yeterliliğin birbiri içerisinde yer alan 5 bileşenden oluştuğunu dile getirmişlerdir:

"1. Matematiği anlama;

2. Akıcı bir şekilde hesap yapma;

3. Problemleri çözmek için kavramları uygulamaya koyma;

4. Mantıksal akı1 yürütme ve

5. Matematiği mantıklı, yararlı ve yapılabilir görerek; matematikle ilgilenme." 


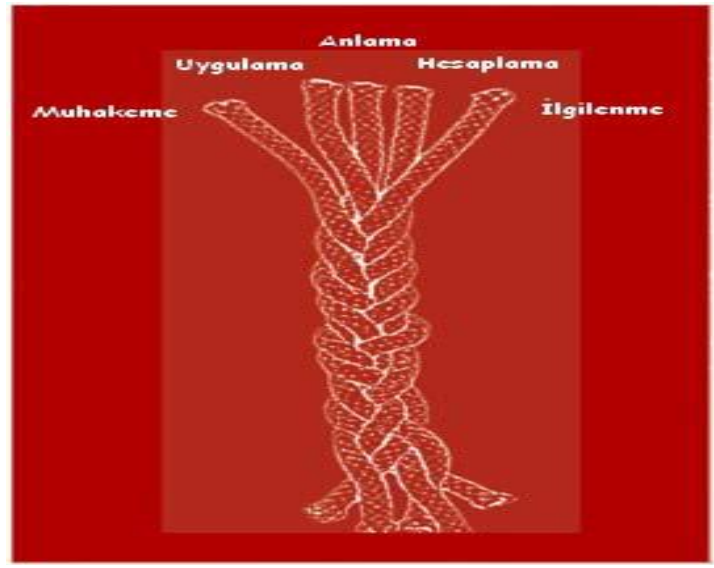

Şekil 1. Matematiksel yeterliliğin iç içe geçmiş 5 bileşeni (Kilpatrick ve Swafford, 2002, p. 8, Akt: Temizöz, 2013)

$\mathrm{Bu}$ beş bileşen daha ayrıntılı bir şekilde ifade edilebilir:

"1.Anlama (Understanding): Matematiksel kavramları, işlemleri ve ilişkileri kavrama matematiksel sembollerin, diyagramların ve işlemlerin ne anlama geldiğini bilme.

2. Hesaplama (Computing): Sayıları esnek, doğru, verimli ve uygun bir şekilde toplama, çıkarma, çarpma ve bölme gibi, matematiksel işlemleri yapma.

3. Uygulama (Applying): Problemleri matematiksel olarak formüle edebilme, kavramları ve işlemleri uygun bir şekilde kullanarak bu problemleri çözmek için stratejiler üretebilme.

4. Muhakeme (Reasoning): Bir problemin çözümünü açıklamak ve doğrulamak için veya bilinen bir şeyden henüz bilinmeyen bir şeye erişmek için mantığı kullanma.

5. İlgilenme (Engaging): Matematiği mantıklı, yararlı ve -eğer üstünde çalışırsanyapılabilir olarak görme ve üzerinde çalışmaya istekli olma." (Kilpatrick ve Swafford, 2002, p. 9; Akt. Temizöz, 2013).

\subsection{Matematiksel Modelleme ve Problem Çözme}

Diğer ülkelerde olduğu gibi ülkemizde de eğitim programlarındaki çağdaşlaşma yolunda yapılan yenilikler devam etmektedir (Okur, Bahar, Akgün, Bekdemir, 2011). 2013 yılında Milli Eğitim Bakanlığ tarafından güncellenen ortaöğretim matematik dersi öğretim programı ile matematik dersinin matematiksel bilgilerin matematiksel iletişimde ve problem durumlarını modelleme ve çözme konusunda güncellenmesi gerektiği üzerinde durulmuştur. $\mathrm{Bu}$ nedenle öncelikle öğrencilerin matematik dersini yararlı ve uğraşmaya değer bulmasının sağlanması ve öğrencilerin sabırla çalışmalarına devam etmeleri gerektiği belirtilmiştir. $\mathrm{Bu}$ bağlamda matematikle ilişkin duyuşsal gelişimler, tutumlar, bireylerin sahip oldukları öz güvenleri ve kaygılarının önemsenmesi gerektiği ifade edilmiştir. $\mathrm{Bu}$ çerçevede, matematik öğretim programının geliştirmeyi amaçladığ 1 matematiksel beceri ve yeterliliklerden bazıları, "matematiksel modelleme ve problem çözme", "matematiksel süreç becerileri: Matematiksel dili ve terminolojiyi doğru ve etkin kullanma (matematiksel iletişim)", "matematiksel akıl yürütme ve ispat yapma", "matematiğin kendi içindeki konular/kavramlar arasında ve başka alanlarla ilişkilendirme" olarak belirtilmiştir (MEB, 2013).

$\mathrm{Bu}$ ifadeler, yeni matematik programında dünya genelindeki gelişmelerle birlikte matematik dersinde öğrenilen bilgilerin günlük yaşama transfer etmede, gerçek hayat problemlerine göre yapılandırmacı amaçların benimsenmesine, matematik eğitiminde 
modellemelere yer verilmesine, problem çözme ispat yapabilme becerisine sahip olunması gerekliliğine önem verildiğini göstermektedir. Ancak matematiğin öğretimde soyut ve ezberlenmesi gereken bir disiplin olarak verilmesi yüzünden birçok öğrenci matematiği günlük hayata nasıl transfer edebileceğini, bu dersin gerçek yaşamda ne işe yaradığını bilmemekte ve bu disiplinin sadece okullarda öğretilen bir dersten ibaret olduğu gibi bir yanlış kanıya düşmektedirler (Deniz, 2014). Derslerde sık sık günlük hayatla ilgili örnekler verilmesi, öğretmenlerin rehberliğinde matematiksel dilin günlük hayata aktarılması gibi etkinlikler bu tür sıkıntıların daha kolay bir şekilde aşılmasını ve programın hedeflerini sağlamasını kolaylaştırabilir.

Lingefjard (2007), matematiksel modellemenin tanımını " matematiği ve matematiğin bir ürün ve süreç olarak nasıl kullanıldığına dair örnekler sunan diğer birçok disiplini bir araya getiren disiplinler arası bir konudur" şeklinde ifade etmiştir (Bulut ve diğerleri, 2010). Başka bir ifadeyle matematiksel model bir durumun önemli faktörlerini yansıtan formül, eşitlik, grafik ve tablo gibi matematiksel form iken; bu modeli geliştirmek için geçen süre ise matematiksel modelleme olarak ifade edilir (The Consortium for Foundation Mathematics, 2008; Bulut ve diğerleri,2010). Talim ve Terbiye Kurulu Başkanlığı' na ait, “Orta Öğretim Matematik $(9,10,11$ ve 12.sınıflar) Dersi Öğretim Programı" nda (MEB, 2013) ise, matematiksel modelleme "hayatın her alanındaki problemlerin doğasındaki ilişkileri çok daha kolay görebilmemizi, matematik terimleriyle ifade edebilmemizi, sınıflandırabilmemizi, genelleyebilmemizi ve sonuç çıkarabilmemizi kolaylaştıran dinamik bir yöntemdir" olarak tanımlanmıştır. Matematiksel modellemelerin bireylere kazandırılması hedeflenen durumlar, öğrencilerin matematiksel düşünme becerilerini geliştirmesi, matematiği günlük yaşama aktarmaları ve matematiğe değer vermeleridir. $\mathrm{Bu}$ hedefe ulaşabilmek için, matematiksel modelleme süreci; uygun değişken ve sembolleri seçme, değişkenlerin arasındaki ilişkileri belirleme, bunların vasıtasıyla gerçek hayat durumunu modelleme ve bu modelin değerlendirilmesini kapsayan dinamik bir süreç olarak ele alınmalıdır. Matematiksel modelleme bir gerçek hayat problemi ile başlar, problemin matematikselleştirilmesi ve elde edilen durumun gerçek hayat için yorumlanması ile tamamlanır. Bu döngüsel süreç aşağıdaki şekilde gösterilmiştir.

\section{Gerçek Dünya Matematik Dünyası}

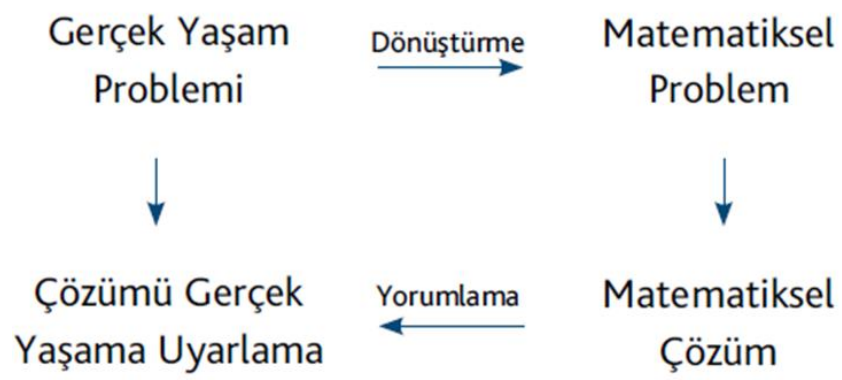

Şekil 2. Matematiksel modelleme ve problem çözme döngüsü (MEB, 2013)

Öğretim programında problem çözmeye dayalı öğrenme ortamlarının planlanmasına büyük önem verilmesinin nedeni öğrencilerin modelleme ve problem çözme becerilerini birlikte geliştirebilmesini sağlayabilmektir (MEB, 2013). Olkun ve Toluk (2003)' a göre problemin 
tanımı, "kişide çözme arzusunu uyandıran ve çözüm prosedürü hazırda olmayan fakat kişinin bilgi ve deneyimlerini kullanarak çözebileceği durumlar" şeklindedir. İyi problem çözebilmek matematikte başarılı olmakla yakından ilgilidir. Matematik öğrenimi ve öğretiminde problem çözme sürecinin nasıl işlediği önemlilik arz etmektedir. Aynı zamanda problem çözmenin bilimsel bir yöntem olması dolayısıyla bu beceri eleştirel, yaratıcı ve yansıtıcı düşünmeyi de gerektirecektir (Soylu ve Soylu, 2006). Bu çerçevede bir bireyin problem çözme yeterliliği, bir problem durumunu kavrama, çözüm için stratejiler üretme, geliştirdiği stratejiyi uygulama ve elde ettiği çözümü doğrulayabilme yeterliliği olarak ifade edilebilir. Eğitim sürecinde tercih edilecek olan problem durumları mümkün olduğu kadar bireylerin yaşamında ihtiyaç duydukları konularla ilgili ve gerçekçi olmalıdır (MEB, 2013).

\subsection{Matematiksel Süreç Becerileri}

\subsubsection{Matematiksel İletişim Sağlayabilme}

Matematik aralarında anlamlı ilişkiler barındıran kendine has sembolleri ve terminolojisi olan evrensel bir dildir. Bu dilin doğru bir şekilde kullanımı matematik başarısı için oldukça önem taşımaktadır (Toptaş, 2015). Ayrıca bu dilin öğrenciler için anlamlı olması onların bu durumu ihtiyaç olarak hissetmelerini sağlayacaktır. Bu sebeple matematik öğretiminde ve matematiksel iletişimde sözlü anlatımdan, yazılı ve görsel ifadelerden yararlanmak oldukça önemlidir. Bu süreçte eğitici sınıf ortamında bireylerin kendi fikirlerini rahatça açıklayabilecekleri, bu düşünceleri tartışabilecekleri ve yazılı olarak gösterebilecekleri ortamı sağlamalı ve onların daha başarılı iletişim kurabilmesi için yerinde sorgulamalar yapmalıdır. MEB Ortaöğretim Matematik Dersi Öğretim Programı' nda yer alan iletişim becerilerini geliştirmeye yönelik hedeflenen bazı kazanımlar şunlardır:

1) Somut model, şekil, resim, grafik, tablo, sembol vb. farklı temsil biçimlerini kullanarak matematiksel düşünceleri(ni) ifade etme, 2) Günlük dili, matematiksel dil ve sembollerle; matematiksel dili, günlük dil ve sembollerle ilişkilendirme, 3) Matematiksel dilin gerçek problem durumlarını sade, anlaşılır ve etkin bir biçimde ifade etme başarısının farkına varma ve bunu takdir etme, 4) Matematiğin sembol ve terimlerini etkili bir şekilde kullanma, 5) Matematiksel dili matematiğin kendi içinde, farklı disiplinlerde ve kendi yaşantısında uygun ve etkili bir biçimde kullanma, 6) Matematik dilini kullanmada özgüvene sahip olma

\subsubsection{Matematiksel Akıl Yürütme ve İspat Yapma}

Matematik ve matematiksel düşünme genellikle bireylerin günlük hayatlarında yaşadıkları problemleri çözmeleri için sıklıkla kullanılır (Arslan ve Yıldız, 2010). Matematiksel bakış açısının geliştirilmesi, matematiksel düşünmedir ve bireye yaşamındaki problemlerin çözümünde yarar sağlar. Matematiksel düşünmenin üst düzey düşünme şekli olmasıyla birlikte matematiksel düşünmeyi tespit etmenin diğer bir yöntemi de bireylerin matematik teoremlerini ispatlama şekillerine bakmaktır (Yılmaz, 2015). İnsanın içgüdüsel olarak sahip olduğu yeteneklerden birisi de matematiksel akıl yürütme ve ispat yapmadır (Altıparmak ve Öziş, 2005). Tsamir ve diğerlerine (2009) göre, ispat yapma farklı bireyler tarafindan incelendiğinde ve uygulama yapıldığında sürekli bir sorgulama ve yeniden doğrulanma süreçlerine tabi tutularak yapılan hatalar, elde edilen belirsizlikler ve yanlış anlaşılmalar bu yolla sürekli bir şekilde giderilmektedir (Zaimoğlu, 2012). 


\subsubsection{Matematiksel İlișkilendirme Yapabilme}

Matematiksel ilişkilendirme, hem matematiğin kendi içinde hem farklı disiplinlerde hem de kendi yaşantısında yapılabilir. Matematiği kendi içerisinde ilişkilendirebilen birey, eski bilgilere dayalı yeni bilgiler oluşturur ve bildiğini düşündüğü kavramları tekrardan yapılandırma şansı elde eder (Umay, 2011). Bodner (2006)' e göre, matematiğin, bilgisayar, dil, fen, sanat, mimari, müzik, dans, tiyatro ve eğitim alanları gibi birçok disiplinle ilişkisi de mevcuttur. Umay (2011), matematiğin diğer bilim dalları içindeki yerinin inkar edilemeyeceğini ve bir dil, düşünme biçimi olan, yaşamın her noktasına yansıyan matematikten yararlanmayan bir bilim dalı olamayacağını belirtmiştir (Özgen, 2013). Mosvold (2008)' e göre, matematiğin günlük yaşam ile ilişkilendirilmesi okulda öğrenilen matematikle dış dünya arasındaki ilişkidir. Umay (2007), matematiğin günlük hayatla ilişkilendirilmesinin, anlamlandırmayı daha da kolaylaştırdığı gibi oldukça soyut bir bilim olan matematiğin somutlaştırılmasına, gerçek olarak algılanmasına da katkı sağlayacağını belirtmiştir.

Bu bölümde, Ortaöğretim Matematik Dersi Öğretim Programının öğrencilere kazandırmayı hedeflediği matematiksel yeterlilik ve becerilere ilişkin açıklamalar yer almıştır. Öğretmen görüşleri temelinde, hedeflenen bu yeterlilik ve becerilerin öğrenciler tarafindan ne derecede kazanıldığının incelenmesi, bu konunun çalışılma nedenlerinden birini oluşturmuştur.

\section{Araștırmanın Amacı}

$\mathrm{Bu}$ çalışmanın temel amacı, Ortaöğretim Matematik Dersi Öğretim Programı nın (912.sınıflar) öğrencilere kazandırmayı hedeflediği matematiksel yeterlilik ve becerilere ilişkin kazanımların ve ulaşılma düzeylerinin öğretmen görüşleri doğrultusunda belirlemektir. Bu temel amaç doğrultusunda aşağıdaki sorulara yanıt aranmıştır:

Ortaöğretim kurumlarında matematik dersini yürüten matematik öğretmenlerinin;

1) Matematiksel iletişim sağlayabilme becerisi için sınıf ortamında yapılan uygulamalara,

2) Öğrencilerinin günlük dil ile matematiksel dili ilişkilendirmede ne derecede başarılı olduklarına,

3) Öğrencilerinin matematiksel ilişkilendirme yapabilme konusunda ne ölçüde başarılı olduklarına,

4) Modelleme uygulamalarının kazanım ve uygulama sürecindeki yerine,

5) Modelleme uygulamalarının ders kitaplarındaki yerine,

6) Öğrencilerinin tümdengelim ve tümevarım davranışlarını ne derecede kullandıklarına,

7) Öğrencilerinin akıl yürütme ve ispat yapma becerisi kazanabilmelerine yönelik öğrenme-öğretme sürecine,

8) Öğrencilerinin bu becerileri etkili kullanmaları için hangi yöntem, teknik ve öğretimsel materyalleri kullandıklarına ilişkin görüşleri nasıldır?

\section{Yöntem}

$\mathrm{Bu}$ başlık altında, araştırmanın modeli, çalışma grubu, verilerin toplanması ve çözümlenmesi konuları ele alınmıştır. 


\subsection{Araștırmanın Modeli}

Bu araştırma Ortaöğretim Matematik Dersi (9, 10, 11 ve 12. Sınıflar) Öğretim Programı' nın öğrencilere kazandırmayı hedeflediği matematiksel yeterlilik ve becerilere ilişkin öğretmen görüşlerini belirlemek amaciyla tarama modelinde betimsel bir çalışma niteliği taşımaktadır. $\mathrm{Bu}$ araştırma nitel bir çalışma olarak desenlenmiştir. Eğitim çalışmalarında kullanılan yöntem ve elde edilen verilerin analiz edilmesi dolayısıyla nitel ve nicel olmak üzere iki temel yaklaşım ön plandadır. Son zamanlarda, sosyal bilimler ve eğitim araştırmalarında baskın çıkan paradigmanın nitel verilere dayalı yorumlayıcı paradigma olduğu fark edilmektedir. Nitel araştırma, gözlem, görüşme ve doküman analizi gibi nitel veri toplama araçlarının kullanıldı̆̆ 1 , doğal ortamda algıların ve olayların gerçeğe yakın ve kapsamlı şekilde ortaya çıkarılmasına yönelik nitel bir sürecin izlendiği araştırma olarak ifade edilebilir (Yıldırım ve Şimşek, 2013). Bu çalışma sadece öğretmen görüşleri alınarak oluşturulmuştur. Görüşme yöntemi, insanların neyi ve neden düşündüklerini, hangi duygu, tutum veya hislere sahip olduğunu, davranışlarını yönlendiren etmenleri ortaya çıkarmayı sağlayan bir veri toplama aracıdır. Kısaca ifade edecek olursak, insanın zihnine ve kalbine girmeyi hedefleyen bilimsel bir araçtır (Ekiz, 2003, s. 61; Akt: Taştepe, 2012).

\section{2.Çalışma Grubu}

Araştırmanın çalışma grubu, Aydın il merkezinde bulunan kamu okullarında görevli 15 matematik öğretmeninden oluşmaktadır. Çalışma grubunun belirlenmesinde gönüllülük esas alınmıştır. $\mathrm{Bu}$ bağlamda görüşme yapılacak öğretmenlere önceden çalışmanın amacı hakkında bilgi verilmiş ve çalışmaya katılmaya gönüllü olan öğretmenlerle görüşmeler yapılmıştır.

Görüşme yapılan öğretmenler belirlenirken, amaçlı örnekleme yöntemlerinden ölçüte dayalı örneklem tekniğinden faydalanılmıştır (Hatch, 2002). Belirlenen ölçütler doğrultusunda, matematik bölümü veya matematik öğretmenliği bölümünden mezun olan ve ortaöğretim kurumlarında en az 5 yıl görev yapmış lise matematik öğretmenleri çalışma grubunu oluşturmuştur. Çalışma grubu belirlenirken öğretmenlerin, farklı okul türlerinden gelmelerine de dikkat edilmiştir. Çalışma grubunun özelliklerine ilişkin veriler Çizelge 1' de yer almaktadır. 
Çizelge 1. Çalışma Grubunun Özellikleri

\begin{tabular}{|c|c|c|c|c|c|}
\hline Kodu & Cinsiyeti & $\begin{array}{l}\text { Meslekteki } \\
\text { Kıdem }\end{array}$ & Okul Türü & Eğitim Düzeyi & Statü \\
\hline K1 & Kadın & $14 \mathrm{y} 11$ & $\begin{array}{c}\text { Güzel Sanatlar } \\
\text { Lisesi }\end{array}$ & Lisans & Kadrolu \\
\hline $\mathrm{K} 2$ & Kadın & $18 \mathrm{y} 1 \mathrm{l}$ & Anadolu Lisesi & Lisans & Kadrolu \\
\hline $\mathrm{K} 3$ & Kadın & $11 \mathrm{y} 1 \mathrm{l}$ & Anadolu Lisesi & Lisans & Kadrolu \\
\hline K4 & Kadın & $18 \mathrm{y} 11$ & Anadolu Lisesi & Lisans & Kadrolu \\
\hline K5 & Erkek & $17 \mathrm{y} 1 \mathrm{l}$ & Anadolu Lisesi & Lisans & Kadrolu \\
\hline K6 & Erkek & 16 yıl & Anadolu Lisesi & Lisans & Kadrolu \\
\hline K7 & Erkek & $31 \mathrm{y} 11$ & Fen Lisesi & Lisans & Kadrolu \\
\hline K8 & Erkek & $15 \mathrm{y} 1 \mathrm{l}$ & Anadolu Lisesi & Lisans & Kadrolu \\
\hline K9 & Erkek & $13 \mathrm{y} 11$ & Anadolu Lisesi & Lisans & Kadrolu \\
\hline K10 & Kadın & $16 \mathrm{y} 11$ & Anadolu Lisesi & Lisans & Kadrolu \\
\hline K11 & Erkek & $17 \mathrm{y} 11$ & Anadolu Lisesi & Lisans & Kadrolu \\
\hline K12 & Erkek & 38 yıl & $\begin{array}{c}\text { Mesleki ve } \\
\text { Teknik } \\
\text { Anadolu Lisesi } \\
\text { (Sağlık Lisesi) }\end{array}$ & Lisans & Kadrolu \\
\hline K13 & Erkek & $12 \mathrm{y} 1 \mathrm{l}$ & Anadolu Lisesi & Lisans & Kadrolu \\
\hline K14 & Erkek & $16 \mathrm{y} 1 \mathrm{l}$ & $\begin{array}{c}\text { Sosyal Bilimler } \\
\text { Lisesi }\end{array}$ & Lisans & Kadrolu \\
\hline K15 & Erkek & $20 \mathrm{y} 1 \mathrm{l}$ & $\begin{array}{c}\text { Mesleki ve } \\
\text { Teknik } \\
\text { Anadolu Lisesi }\end{array}$ & Lisans & Kadrolu \\
\hline
\end{tabular}

\subsection{Veri Toplama Aracı}

Araştırmaya ilişkin veriler araştırmacılar tarafından geliştirilmiş olan "yarı yapılandırılmış görüşme formu" aracılığı ile toplanmıştır. Görüşme formunun yapılandırılması sürecinde, matematik dersi öğretim programında yer alan kazanım ve yeterlik alanları incelenmiş, literatür taraması yapılmış ve pilot uygulama için taslak sorular oluşturulmuştur. Formun pilot uygulaması çalışma grubundan farklı olarak, ortaöğretim kurumunda görev yapan 1 matematik öğretmeni ile gerçekleştirilmiştir. Araştırmacının ön denemesi sonucunda görüşme formu yeniden incelenmiş ve görüşme formuna son biçim verilmiştir. Form, toplam 14 esansiyel sorudan oluşmaktadır. Görüşme formu ekte verilmiştir.

\subsection{Verilerin Toplanması ve Analizi}

Görüşmeler, çalışma grubunu oluşturan lise matematik öğretmenleri ile okulların dersliklerinde yapılmıştır. Bu süreçte formda yer alan sorulara öğretmenlerin verdikleri yanıtlar onların izinleri dahilinde ses kayıt cihazı ile kaydedilmiştir. Her bir görüşme ortalama $35 \mathrm{dk}$. sürmüştür.

Görüşmeler yoluyla elde edilen verilerin analizinde, nitel veri analizi tekniklerinden tipolojik analiz kullanılmıştır (Hatch, 2002). Analiz sürecinde her bir alt amaçla ilişkili olarak görüşme soruları birer tema/boyut biçiminde ele alınmıştır. Her bir temanın içindeki anlam birimleri, literatür doğrultusunda ortaya çıkarılmış ve bu anlam birimleri aracılığıyla da kuramsal açıklamalara dayandırılarak çıkarsamalar yapılmıştır. 
Araştırma sonucunda öğretmenlerden elde edilen verileri kimliklerini açıklamadan sunabilmek ve karışıklık yaşanmasını engellemek için kodlama yapılmıştır. Görüşme yaptığımız ilk öğretmene K1 ve görüşme sırasına göre her bir öğretmene sırasıyla ("K2", "K3", "K4"... "K15”) şeklinde kodlar verilmiş̧ir. Nitel verilerin raporlaştırılması aşamasında, bulgularla ilgili olarak, görüşmelerden birebir alıntılar yapılarak, güvenirlik arttırılmaya çalışılmıştır. LeComte ve Goetz (1982; Akt, Yıldırım ve Şimşek, 2006), toplanan verilerin öncelikle betimsel bir yaklaşımla doğrudan sunulmasının, gözlem, görüşme ve dokümanlar yoluyla topladığ 1 verileri herhangi bir yorum katmadan okuyucuya sunulmasının ve araştırmacının yorumlarını daha sonraya bırakmasının nitel araştırmalarda güvenirliği artırmada oldukça önemli olduğunu vurgulamaktadır. Araştırma sonucunda elde edilen bulgular, herhangi bir yoruma yer verilmeden ayrı başlıklar halinde, sık s1k doğrudan alıntılara yer verilerek sunulmuştur. Daha sonra bu bulgular tartışma kısmında bütün olarak ele alınıp tartışılmıştır.

Tablo 1. Tema ve kod listesi örneği

\begin{tabular}{|c|c|}
\hline Tema & Kodlar \\
\hline $\begin{array}{l}\text { Matematiksel iletişim sağlayabilme } \\
\text { becerisini geliştirmeye yönelik sınıf } \\
\text { ortamında yapılan uygulamalar }\end{array}$ & $\begin{array}{l}\text { Akıllı tahta } \\
\text { EBA Programları } \\
\text { Resimleştirme/ Görselleştirme } \\
\text { Konuya etkinlikle başlama } \\
\text { Gerek duymama } \\
\text { Ders kitaplarındaki etkinlikler } \\
\text { Geogebra } \\
\text { Bireysel farklılıklar }\end{array}$ \\
\hline $\begin{array}{l}\text { Öğrencilerin günlük dil ile } \\
\text { matematiksel dili ilişkilendirmede } \\
\text { başarı düzeyi }\end{array}$ & $\begin{array}{l}\text { Başarılı } \\
\text { Başarısız } \\
\text { Hazırbulunuşluk } \\
\text { Sınav sistemi gerçeği }\end{array}$ \\
\hline $\begin{array}{lr}\text { Öğrencilerinin } & \text { matematiksel } \\
\text { ilişkilendirme } & \text { yapabilme } \\
\text { konusundaki başarı düzeyi }\end{array}$ & $\begin{array}{l}\text { Farklı disiplinlerde başarısız } \\
\text { Farklı disiplinlerde başarılı } \\
\text { Kendi yaşantısı } \\
\text { Matematiği hayatımızda nerede kullanacağız? }\end{array}$ \\
\hline Modelleme uygulamaları & $\begin{array}{l}\text { Nadir yapılıyor } \\
\text { EBA } \\
\text { İlgisizlik } \\
\text { Tablet kullanımı } \\
\text { Uygun konu seçimi } \\
\text { Hizmet içi eğitim yetersizliği } \\
\text { Zaman yetersizliği } \\
\text { Müfredatı yetiştirme zorunluluğu } \\
\text { Eskiye oranla etkinliklerde artış } \\
\text { Somutlaştırmaya karşı olma }\end{array}$ \\
\hline $\begin{array}{l}\text { Ders kitaplarında modelleme } \\
\text { uygulamalarına yer verilme sıklığ } 1\end{array}$ & $\begin{array}{l}\text { Çok az } \\
\text { Öğrenci seviyesine uymuyor } \\
\text { Giderek artıyor } \\
\text { Temel matematik dersi } \\
\text { İçerik yetersizliği } \\
\text { Çok başarılı } \\
\text { Zaman sıkıntıs1 }\end{array}$ \\
\hline $\begin{array}{l}\text { Tümdengelimi ve tümevarımı } \\
\text { kullanma sıklığ1 }\end{array}$ & $\begin{array}{l}\text { Tümevarım } \\
\text { Tümdengelim } \\
\text { Standartlaştırma isteği } \\
\text { İpucu }\end{array}$ \\
\hline
\end{tabular}




\begin{tabular}{ll}
\hline Öğrencilerinin akıl yürütme ve ispat & İyi iletişim \\
yapma becerisi kazanabilmelerine & Yarısı çekinik \\
yönelik yapılan etkinlikler & Konudan konuya değişim \\
sırasındaki iletişim & İspat zor ve soyut \\
& Zorlanma \\
& Özgüven eksikliği \\
& Gereksiz bulma \\
& S1kılma \\
& Hazır bilgi isteme \\
& İlgisizlik \\
& K1sa ispatları tercih etme \\
\hline Hedeflenen becerileri & Düz anlatım \\
kazandırabilmek için derslerde tercih & Soru cevap \\
edilen yöntem ve teknikler & Dikkat çekme \\
& Beyin Fırtınası \\
& Hikayeleştirme \\
& Konuya göre drama \\
& İstasyon tekniği \\
& Buluş yöntemi \\
& Grup çalışması \\
& Problem çözme \\
& Öğrencinin öğretmen rolüne girip ders anlatması \\
\hline Hedeflenen & Akıllı tahta \\
kazandırabilmek için derslerde tercih & EBA programları \\
edilen materyaller & Tablet \\
& Eğlence oyunları \\
& Videolar \\
& 3 boyutlu cisimler \\
& Geometrik cisim programları \\
& \\
\hline & becerileri \\
& \\
&
\end{tabular}

\section{Bulgular}

Araştırma sonucunda elde edilen bulgular, araştırma amaçları doğrultusunda alt başlıklar altında aşağıda sırasıyla yer almaktadır.

\subsection{Matematiksel İletişim Sağlayabilme Becerisini Geliştirmeye Yönelik Sınıf Ortamında Yapılan Uygulamalar}

Öğretmenlerin matematiksel iletişim sağlayabilme becerisini geliştirmeye yönelik sınıf ortamında yaptıkları etkinlikler hakkındaki görüşleri incelendiğinde, 6 öğretmen akıllı tahtaları yoğun bir şekilde kullandıklarını belirtmiştir. 2 öğretmen (K1 ve K4) öğrencilerin hazırbulunuşluk düzeylerinin yetersiz olmasından dolayı bu uygulamaları çok fazla yapamadıklarını, 2 öğretmen (K9 ve K13) müfredatı yetiştirme zorunluluğundan dolayı bu becerileri geliştirmek için gerekli olan süreyi ayıramadıklarını, 1 öğretmen (K9) ders kitaplarında verilen etkinlikleri uyguladığını, 1 öğretmen (K11) Geogebra yazılımından faydalandığını ve 2 ögretmen (K13 ve K15) eğitimde bireysel farklılıkların bulunduğunu ve bu yüzden bu uygulamaların bireysel uygulamalar olması gerektiğini ifade etmiştir.

K3: Derslerimde akıllı tahtayı kullandı̆̆ım için bu tür uygulamalar bizim için çok zor olmuyor. Grafik çizme, şekil çizme ve bunun gibi beceriler kazandırmamız normal tahtaya göre bizim için daha kolay. Öğrencilerin kendilerinin şekil çizmesine, tahtaya çılkı akıllı tahtayı etkili olarak kullanmasına yardımcı oluyoruz. Bu da bizim için bir avantaj. 
K11: Aslında daha çok materyal yerine akillı tahtalardaki uygulamaları kullanıyoruz. Sinıf ortamında grafikleri gösterebilmek için bir program vardl: "Geogebra". Parabollerin çizimi ile ilgili onları kullanıyoruz. Oradaki şekil değişimlerini gösteriyoruz. Daha çok materyal değil de akıllı tahta uygulamaların kullanıyoruz.

K9 ve K13' ün yanıtları müfredatı yetiştirme zorunluluğundan dolayı bu tarz uygulamaları yapmakta zorlandıklarını göstermektedir:

K9: Illk etapta ders kitaplarında verilen etkinlikleri uygulamaya çalışlyoruz. Her ne kadar ders saatimiz 6 saate kadar çıkartılsa da, bazı konularda kısitlamalar yapılsa da bu durum ögrencilerin matematik ögretimi için yeterli değil. Hala daha fazla süreye ihtiyacımız olduğunu düşünüyorum.

K13: Eğitimde bireysel farklılıklar var. Kimisi görerek kimisi dokunarak kimisi işiterek anliyor. Matematik eğitiminin başarılı olabilmesi için zaten çocukların bilişsel yapılarına göre kategorize etmek lazım. Görsel anlayanlara görsel materyallerle hitap edecek sinıflarda ders anlatılmast, işitsel anlayanlara o tarz gibi yani bireysel farklilıkları ne kadar çok bir araya getirip o şekilde ifade edersek herkesin anladiğ dilden konuşuruz. Derslerimizde kullaniyoruz ama tabi mümkün mertebe müfredatı yetiştirme zorunluluğu bize de kendi isteklerimizi kendi çalışmalarımızı zorlaştırıyor diyebiliriz.

Fen lisesinde görev yapmakta olan matematik öğretmeni, bu becerileri geliştirmeye yönelik yapılan uygulamalara gereksinim duymadığını vurgulamıştır:

K7: Çok fazla sembol hani görsellik sinıf düzeyinde çok fazla kullandığım söylenemez yani ama bide bizim okulda artık zaten ögrenciler bu perspektifi bilen ögrenciler. Matematiği belirli aşamalarını bitirmiş ögrenciler olduğu için onlardan böyle bir talep çok fazla gelmiyor yani. Biz matematikte görseli çok fazla kullanma gereksinimi duymuyoruz yani.

\section{2.Öğrencilerin Günlük Dil ile Matematiksel Dili İlişkilendirmede Başarı Düzeyi}

Öğretmen adaylarının öğrencilerinin günlük dil ile matematiksel dili ilişkilendirmedeki görüşlerine bakıldığında K3, K4, K6, K7 ve K8 dışında 10 öğretmen öğrencilerini başarısız bulmuştur. Öğretmen görüşlerinden bazı örnekler aşağıda verilmiştir:

K3: Günlük dille, matematiksel dil çok fazla uyuşmasa da bir problem okuduğu zaman o problem de günlük dili verilen problemin matematik diline çevirmeyi biliyor yani bir problem verildiğinde ne demek istediğini, verilenlerin ne olduğunu istenilenlerin ne olduğunu elimizdeki verilere matematiksel dile çevirmeyi yapabildiklerini düşünüyorum.

K5: Yani çoğunlukla şey yapıyorlar. Yani dersi tam böyle yaşama uygulayacaklarını düşünmüyorum ama tabii ki bazı şeyler de pratik olarak lazım oluyor hesap işlerinde falan. Ama çoğunlukla yaşama çok katmıyorlar diye düşünüyorum ben.

K8: Evet, mesela genelde cümleyi bağlarken (+) işaretini kullaniyorlar. "Limit" kelimesini kullanan ögrencilerimi biliyorum günlük hayatta.

K13: Zaten en sık karşılaşstğımız sorunlar günlük hayatımızda nerede karşımıza çıkıyor nerede karşılarına çıkacaklarını bilmedikleri için çok da ilişkilendireceklerini düşünmüyorum. Biraz TEOG sinavı sinav sisteminden dolayı ezberci geldikleri için öyle bir sistemimiz yok daha doğrusu çocukları suçlamayalım. 
Bir öğretmen mevcut olan merkezi sınav sistemi yüzünden öğrencilerinin bu tür becerileri kazanamadığını şu şekilde ifade etmiştir:

K14: O konuda hala sıkıntılar yaşıyoruz. Özellikle bu okulda sıkıntı yaşıyoruz. Benim okulumda çok ilgili bir grup yok biraz geri plandalar matematik konusunda ama mevcut sistemde aslında sınav sistemi de aslında çocukların matematik diline çok yoğun bir şekilde kullanmasını engelliyor. Çocuklara klasik yöntemleri yine aktarmaya çallşlyoruz elimizden geldiği kadar ama çok yoğun bir şekilde yapamıyoruz bunu. Test uyguluyoruz daha çok hızlı olmayı amaçliyoruz. Çünkü sınav sistemi bunu gerektiriyor. Dolayıslyla da bu dili çok kullandıklarından emin değilim. Çok yoğun bir şekilde kullanmadıklarını düşünüyorum.

\section{3.Öğrencilerinin Matematiksel İlişkilendirme Yapabilme Konusundaki Başarı Düzeyi}

Öğrencilerin matematiksel ilişkilendirme yapabilme yeterliliklerine ilişkin, dokuz öğretmen öğrencilerini başarılı bulduğunu, K1, K3 ve K11 başarısız ve K2, K13 ve K15 kısmen başarılı bulduklarını belirtmiştir. Öğrencilerin matematiği kendi içinde ve farklı disiplinlerde ilişkilendirmede başarılı olduklarına ilişkin bazı öğretmen görüşleri şu şekildedir:

K5: Ya tabii ki matematik dersi bir fizik dersi olsun bir kimya dersi olsun özellikle bunlarda bir aktarım var sonuçta. Bu fizik dersinde kimya dersi bir alt yapısı oluşturuyor. Onun için tabii ki oradaki verileri falan kullanabiliyorlar.

K6: Tabii ki fizik dersini özellikle işbirliği yapılabiliyor. Bazı konularda özellikle on ikinci sinıftaki konularda fiziksel yorumlar var. Türevle ilgili onları da açıkllyoruz. Dolayısıyla çocuk iki dersin arasındaki yakın ilişkiyi hissetmiş oluyor.

K8: Matematik şimdi mesela fizik, kimya ya da özellikle fizik, matematik olmadan fizik becerisi zaten olmuyor. Zaten matematikçiler şey söyler "fizikçilerin alet çantası matematiktir". Bence matematik olmadan fizikçiler hiçbir şey yapamıyor. Bir öğrencide matematiğin fizikte veya kimya da kullanıldığını hem biz ögretmenler olarak belirtiyoruz hem de ögrenci de fizik veya kimya dersinde fark ediyor. Örneğin logaritmanın kimya sanayisinde kullanıldığını, çok küçük sayılar olduğunu, işte ne bileyim sinüs kosinüs tanjant kotanjantın fizikte çok fazla kullanıldı̆̆ını ivmeleri falan hesaplarken kullanıldığını, sürtünme katsayılarını hesaplarken kullanıldı̆̆ını bunları her konu başlı̆̆ geldiğinde bir nevi bahsediyoruz. Örneğin mesela bir integralin coğrafya da herhangi bir ülkenin şeklini, alanını bulmak bunu hesaplarken bir karenin dikdörtgenin alanını bulabilir ama çocuk işte Türkiye haritasını Türkiye'nin ölçümü nedir dediğiniz zaman bunun hesaplamasında integral kullanıldı̆̆ını ve benzeri o konunun neye yaradı̆̆ını bunun gibi şeyleri bahsediyoruz.

K4: Öğrencime alan hesaplamaları ile ilgili ödev vermiştim. Öğrencimin yaklaşık bir yıl sonra yapılan proje uygulamalarında bunu kullandığını gördüm. Prefabrik bir ev yaparken yatağın, lavabonun, yemek masasının katlanıp duvara yapışması, açılırken sırayla açılması gerektiği noktalarında alan hesaplamaları kullanmıştı.

Mesleki ve teknik anadolu lisesinde (Sağlık meslek lisesi) çalışan matematik öğretmeni ise konuyla ilgili şu ifadeleri kullanmıştır: 
K12: Bazen mesleğimiz gereği bizim bölüm olarak "oran ve orantı", "yüzdeler”, "simetri kavramı" özellikle öğrencilerin bu becerileri kazanması gerektiğini vurguluyoruz. Meslek hayatlarında kullanacakları bölümler olacak. Bazen çocuk soruyor. "Hocam biz nerede kullanacağız yüzdeleri?". İlaç karıştıracaksınız ya da ilaçların oranlarını belirleyeceksiniz. Yüzde ve orantıyı çok iyi bilmeniz gerekiyor. Simetri kavramını daha iyi yapmaları için çok iyi kavramaları gerektiğini belirtiyoruz. Bazen sargı bile kesseler bunu ölçülü bir şekilde simetrik yapmaları gerekiyor. Yüzdeler milim olarak verilir. Bunlar karıştırllır ve hastaya enjekte edilir. Öğrenci bunu yapmasını bilmeli başka türlü yapamaz. Biz onların bazen zor durumda kaldıklarını biliyoruz.

Öğrencilerin başka disiplinlerde başarısız olduklarına ilişkin bir öğretmen görüşü aşağıda verilmiştir:

K15: Başarısızlar. Matematiği kendi içerisinde anlayamıyorlar ki farkı derslerle ilişkilendirsinler.

Öğrencilerin başka disiplinlerde kısmen başarılı olduklarına ilişkin bazı öğretmen görüşleri ise şunlardır:

K1: Dönüt aldıklarım var ama bir elin parmağını geçmeyen 45 kişi anca. Türkçeyi bile yapamıyorlar. Sayısal ders değil kültür ögretmenleriyle konuştuğumda benim dersimde başarısız olanlar edebiyatta da başarısı tarihte de başarısız benim dersimde başarılı olan diğer derslerde başarıll.

K13: Fizikte kullandıklarını söylüyorlar. Yani onun dışında çok bir geri dönüşyok.

Öğrencilerin matematiği kendi yaşantısıyla ilişkilendirme başarısı hakkındaki bir öğretmen görüşü aşağıda verilmiştir:

K9: Bu aslında matematiği günlük hayata aktarmak gibi bir şey. Mesela ağaç dikme etkinliklerinde yapıyoruz zaman zaman. Internette araştırmasını yapıyoruz. Mesela çam ăgacı dikeceğiz. $O$ iki çam ă̆acl arasındaki uzaklı̆̆a bakmamı gerekiyor. Internetten araştırlyoruz. Kaçar metre aralıklarla dikersek birbirlerine zarar vermeden sağllklı bir şekilde büyürler ya da okulun ön bahçesine dikmistik. Öncelikle bir alan hesabı yaptık. En azından bir fizibilite çalışması yapmış olduk orada.

\subsection{Modelleme Uygulamaları}

Modelleme uygulamalarının ne sıklıkta yapıldığını belirlemeye yönelik veriler incelendiğinde, sekiz öğretmenin modellemeleri kullanmadığ 1 , geriye kalan yedi öğretmenin ise modelleme uygulamalarını kullandığ 1 sonucuna ulaşılmıştır. Öğretmenler genel olarak, modelleme yaparken ak1llı tahta ve EBA' daki görsel derslerden yararlandıklarını belirtmişlerdir. $\mathrm{Bu}$ çıkarımlarla ilgili öğretmen görüşleri aşağıda verilmiştir:

K5: Ara sıra yapıyoruz da özellikle onuncu sınıflarda çok fazla yetiştiremiyoruz ama gene de yapmaya çallşıyoruz. Geçen de bir parabol konusu vardı. Parabol konusunda bir grafik çizimi vardl. Onlardan istediklerim mesela bir parabol grafiği çizin. Aynısını tabletten, matematik programından giriş yaparak grafik çizimlerini karşılaştırdılar, gördüler, kendi yanlışlıklarını gördüler, karşılaştırdılar ve tabletten nasıl yapılabildiğini gördüler. Onlar için iyi oldu diye düşünüyorum. Tabii ki bunun dışında başka şeyler de yapıyoruz. Mesela 
iki kare farkı ispatı mesela veya bir benzerlik alanında "piramitlerle bir güneş yansıması" ile ilgili benzerlik kullanılıyor. Yani yeri geldiği zaman kullanılıyor ama çok sıklıkla değil.

Modellemelere harcayacakları zamanı daha fazla soru çözerek değerlendirmeyi düşünen K10, müfredatı yetiştirme zorunluluğundan dolayı zamanın yetmediğini, okul dışında ekstra zamana ihtiyaç duyulduğunu belirtmektedir. Ayrıca eğitim sisteminin öğrenciyi araştırmaya yönelten bir sistem olmadığından yakınmaktadır:

K10: Okulda yapılan bu tip çalışmalar ona üniversite sınavinda herhangi bir katkı sağlamayacak. Onun yerine buraya harcayacağı zamanı yeni bir kitap alarak soru çözüyor. Bu becerileri açıkçası okulda geliştiremiyoruz. Zamanımız olmuyor. Müfredat yetiştirmeye çalışıyoruz bunun için ekstra bir süre olması gerekiyor. Öğrenciyi dersten önce çağıracă̆ım, dersten sonra çă̆ıracă̆ım. Öğrenci sürekli gelemeyecek. Son sinıflara zaten bu tarz etkinlikleri hiç katmiyoruz. Biz de kolay kolay fedakarlık yapamıyoruz. Asıl amaç okulda analiz senteze, araşstırmaya yönlendiren bir sistemimiz yok ki bizim daha çok sinav. O yüzden bu konuda çocukların becerisi gelişmiyor.

K14: Okulda dediğim gibi projelerin ve ödevlerimi bunlara yönelik vermeye çalışıyorum. Öğrencilere tablolar hazırlattırlyorum. Ĕger konumuz trigonometri ise bir "trigonometri cetveli" hazırlamaya çalışıyorum. Daha çok görsel şeyler ve eğlenceli şeyler yaptırmaya çalışıyorum. Aslında faydası olduğunu düşündüğüm için yaptırıyorum. Her şeyden önce ögrencinin bunu yapıp getirdiği de bunun bir yerde sergilenmesi ve başka ögrenciler tarafindan görülmesi ögrenciye ayrica motive ediyor.

K9, bu konuyla ilgili hizmet içi eğitimin oldukça yararlı olabileceği görüşünü savunmaktadır:

K9: Sadece problem çözme aşamasında bunları yapıyoruz. Aslında bizde eğitim almadık bu modellemeler konusunda. Bu konuda matematik öğretmenlerine yönelik hizmetiçi eğitim verilmesi çok önemli aslında. Burada doğaçlama yürüyor diyebiliriz. Panolar hazırlamak gibi. Karmaşık sayılar konusunda nerede kullanıldığını anlatırken, bunu diyorum ki bir efekt teknolojisi, patlama sahnelerinde, "kardioid" dediğimiz ĕgriler var ya onların bilgisayar uygulamalarında kullanilyyor diyorum. Bununla ilgili "Geogebra programı" vardı şekillerin nasıl çizildiğiyle ilgili. Bununla ilgili Denizli’ de bir eğitime de gitmişstim.

$\mathrm{Bu}$ konuyla ilgili K13, çok farklı bir bakış açısıyla yaklaşarak modellemelere karşı olduğunu, somutlaştırmanın ortaöğretim düzeyindeki akademik matematiğe ters bir yaklaşım olduğunu belirtmektedir:

K13: Yani kişisel olarak ben somutlaştırmaya karşıyım. Matematiğin varoluş sebebi soyut olması değil mi? Matematiğin somutlaştırılması bizi bu dersin amacından uzaklaştıracak. Yani soyut ögrenen çocuklar daha başarll oluyorlar. Bence soyut öğrenen çocuk somut ögrenen çocuklara göre daha başarılı oluyor. Soyut öğrenen çocuk yorum yapabiliyor. Benim lise döneminde teorem ispatı vardı. Sinavlarda teorem ispatı falan sorulurdu. Biz onu yapardık. Sonra karşımıza soru çıktığında değişik sorular çıktığında yorum yapardık. Daha iyi yorum yapardık. Şimdi çocuklar o yorumu yapamıyorlar. Farklı bir soru gördügünde "Öğretmenim bu soruyu bize göstermediniz?" diye tepki veriyorlar. Biraz düşünce tembelliği oluştu. Bunun etkisi sadece sistemden değil günümüze iletişim araçları televizyonda tablette telefonda bunlar zaten hep 2 boyut, 3 boyutlu düşünemiyorlar. Çocuklarda derinlik kavramı yok oldu. 


\subsection{Ders Kitaplarında Modelleme Uygulamalarına Yer Verilme Sıklığı}

Öğretmenlerin ders kitaplarında matematiksel modelleme uygulamalarına ne ölçüde yer verildiği ile ilgili sorulara ilişkin öğretmen görüşleri değerlendirildiğinde, 6 öğretmen olumlu, 9 öğretmen olumsuz cevap vermiştir. Kitapların bu konuda yetersiz olduğunu ifade eden öğretmenler, "kitaplarda çok zor etkinlikler olduğunu", "içeriğinin zenginleştirilmesi gerektiğini”, "örneklemelerin yetersiz kaldığını" , "amacına uygun olmayan örneklerin bulunduğu", "modellemeler yerine soru sayısının fazla olduğu" şeklindeki düşüncelerini ifade etmişlerdir. 11.sinıf temel matematik dersinin modelleme örneklerini daha fazla içerdiğini düşünen $\mathrm{K} 2$, aynı zamanda öğrencilerinin de bu dersi oldukça sevdiklerini belirtmektedir:

K2: Giderek artıyor. Yeni kitaba bakıyorum. Biraz önce verdiğim örnekler fonksiyonlar olsun trigonometri olsun kitaplarda yok. Araştırarak bulabiliyorsun ama birkaç tane daha olsa ender görebiliyorsun. Çok az ama yeterli değil bence. On birinci siniflarda temel matematik dersi var. O ders hoşuma gidiyor. Daha çok örnek var. Kekin maliyetini hesapliyoruz, "unun kilosu ne mesela? Şu kadar un gidiyor, kilosu şu kadardan bu kadar para harcaniyor". "Hocam biz bu kadara mi allyoruz, bu kadara mi mal ediyoruz?" diyorlar. "Evet diyorum, siz nasıl düşünüyordunuz?". "Hocam çok güzel ders" diyorlar. Zaten problemlere girdiğin zaman onlar da soyuttan somutlaştırllabiliyor.

K4: Kitaplarda matematiksel modelleme uygulamalarına dair fazlasiyla ütopik bilgiler mevcut. Öğrenciler; örneğin, bir işlem önceliğini, fonksiyonlarl, karmaşık sayılarl veya türevi uygulama alanı bulamıyor. Sadece ders konusu olarak algllyor. Derse ilginin artması noktasında ders kitapları oldukça yetersiz. Bu noktada ögretmen fonksiyonu işe giriyor. Öğrenciyi yönlendiriyor.

K8: Çok az hiç denecek kadar az. Zaten matematik kitapları bana göre çok yetersiz.

Modellemelerin kitapların içerisinde yer aldığını ancak bu etkinlikleri uygulayamadıklarını, bunun sebebi olarak da müfredatı yetiştirme baskısıyla zaman problemi yaşadıklarını ifade eden öğretmenlerin görüşleri aşağıdaki gibidir:

K9: Bu ülkemiz için yeni bir kavram. Ne zaman ki lise 4 yıla çıkarıldı. Ders kitaplarında yeni yeni bu uygulamalara geçiş yapıldı. Ancak üniversitede hazırladiğımız o materyaller hazırlama dersindeki modeller aklımıza geliyor. Üzerimizde müfredat yetiștirme baskısı var. Yeterli zamanımız olmuyor. Kitaplardaki etkinlikleri takip ediyoruz.

K11: Baya iyi yani daha çok deneme yöntemine dayalı modelleme yöntemine dayalı anlatılmıs ama o tür verileri sınıf ortamında taşıdığınız zaman konu yetiştirme zaman problemi yaşıyorsunuz yani verilen zaman dilimiyle öğretilmeye çalışılan modelleme sistemi birbirini tutmuyor. O yüzden de programda geri kalıyoruz. O yüzden biz modellemeye bırakıp tekrar eski yöntemle anlat çözdür modeli uyguluyoruz.

K14: Çok basit bir biçimde yer alıyor. Ben bu okulda görev yaptı̆̆ım sürece yurt dışına da gittim. Porto'da da bulundum ve Porto' daki matematiğin nasıl işlendiği ve nasll anlatıldığına şahit oldum. Açıkçası hatta oradan bir örnek kitapta getirdim. Bizim kitaplarınızdan çok daha ince çok daha az. Örneğin ne olduğunu tamamen anlamaya yönelik. Modellemelerin gerçekten çok fazla yapıldı̆̆ örnekler mevcut kitapta, tamamen uygulamaya yönelik. Bizim kitaplarımız tam tersi. Ne kadar çok soru çözebiliriz acaba çocukları soru tiplerine ne kadar alıştırabiliriz diye uğraşıyoruz ama yurtdışında böyle 
değil. Yurtdışında böyle bir sinav kaygısı yok. Öncelikle bence bu sistem böyle devam ettiği sürece bu modellemelerin çok fazla kullanilabileceğini düşünmüyorum. Sinav sistemi ile ilgili somut bir adım atılması gerektiğini düşünüyorum.

\subsection{Tümdengelimi ve Tümevarımı Kullanma Sıklığı}

Öğretmen adaylarının tümdengelim ve tümevarım konusundaki görüşleri incelendiğinde öncelikle öğretmenlerin çoğu basitten zora doğru gitmeyi temsil eden tümevarım yöntemini kendilerinin ve öğrencilerinin siklıkla tercih ettiklerini ifade etmiştir. K1 ve K4 ise öğrencilerinin tümdengelimi daha çok tercih ettiklerini belirtmiştir. K13 ise konudan konuya göre tercih edilen yaklaşımın değiştiğini ifade etmiştir.

K2: Tümdengelim pek fazla kullanılmıyor. Tümevarım daha güzel. Parça parçalardan sonra tüme gidebiliyoruz yani nasıl desem tümdengelim yöntemi pek kullanamiyorum ama tümevarım yöntemini daha çok kullanabiliyorum. Parça parça bilgileri verdiğimizde sonrasinda birleştirebiliyorlar ve daha iyi anlıyorlar.

K4: Öğrencilerin çoğunlukla tümdengelimi kullandiğını görüyorum. Eğitim anlamında tümevarım ögretim anlamında tümdengelim demek yanlış olmaz. Yaşanan aksaklıklar ögrencilerin hazırbulunuşluğunun eksik olması. Buna eğitim programı da etken. 9.sınıf konularının bir bölümü 10.sınıfta gösteriliyor. Ancak 9.sınıfta temel alamayan öğrenci 10.sınıfta sorun yaşıyor. 11.sınıfta görülen karmaşık sayılar konusundaki bilgilerin kullanımının devam etmemesi ögrencinin unutmasına neden oluyor.

K13: Tümevarım yapsa varamiyor, tümden gelmeye kalksa gelemiyor öyle bir durum var yani. Çok karamsar bir tablo mı çizdim bilmiyorum ama hiç düşünmedim. Toplam çarpım sembollerinde tümevarım formülü işleniyor ama dediğim gibi uyarlama işi, somutlaştırma işi bana biraz pek hoşuma gitmiyor. Konunun yapısına göre kimi zaman tümevarım, kimi zaman tümdengelim kimi zamanda olmayana ergi konunun yapısina ve içeriğine göre değişir seçeceğimiz yöntem zaten tek konuya bağlı kalmak aptallık olur.

Öğretmenlerin bu süreçte yaşadığı aksaklıklar şu şekilde belirtilmiştir:

K7: Yani biz bu fen lisesine ilk geldiğimiz yıllarda işin teorik kısmı ile çok uğraşıyorduk. İspatıdır. Tümdengelimdir. Bir teorem nasıl yazılır? Ben 9. Sinıfa gelen bir çocuğa ilk dersten sorarım. Bir açıortay tanımı yapabilecek misiniz? Bir üçgen tanımı yapabilir misiniz? En zor işlerden biridir. Herkes tanır, çok iyi bildiğini zanneder. Tanım yapmak çok farklı bir şey hele hele matematiksel tanım yapmak çok farklı bir şey. Bu işin teorik klsmı ile ilgilendiğimiz süreçler oldu. O zamanlar farklı idi biraz daha. Bizim okulda alınan eğitimin derinliğine girebiliyorduk. Ben son zamanlarda, ilk 5-10 yllda sorduğum soruların çoğunu soramıyorum mesela. Tamamen üniversiteye ögrenci hazırlayan kurum haline getirdiler fen liseleri de dâhil.

K11: Yok, özellikle koordinat düzleminde böyle bir şeyler yapmaya çalıştım. Kendi adıma ve bunu bir türlü anlatamadım. Bildikleri formülleri aslında soruya dayalı çözdürmeye çalıştım. Soru olarak sordum. Soru içinde herhangi bir sayı geçmediğinden dolayı başarılı olamadılar. İçsel olarak çözümleyemiyorlar verdiğimiz örneği. İçsel olarak çözümleyemedikleri için uygun cevabı veremiyorlar.

Öğrencilerin matematik dersindeki bilgileri standartlaştırmaya çalıştıklarını ifade eden K13, öğrencilerde özgür düşüncenin giderek azaldığından yakınmaktadır. 
K13: Bu tarz akll yürütme becerilerinde çok zayıflar. Sadece kendi okulum için değil, genel olarak yeni kuşakta aldıkları eğitimin sonucunda büyük bir hezimet var. Birebir birakın farklı örnekleri çözmeyi birebir örneğin konunun formülün aynı örneklerle sorulduğunda bile çoğu öğrenci yanitlayamıyor. Çok ezberciler her konuya anlattığında sinıftan gelen şu cümleler "Hocam artık hep bu şekilde mi yapacağız?" "Hep bunu gördüğ̈̈müz hep böyle mi yapacağız?" standartlaştırmaya, ezberlemeye çalışıyorlar. Halbuki matematikçi biraz özgür düşünebilmeli.

\section{7.Öğrencilerinin Akıl Yürütme ve İspat Yapma Becerisi Kazanabilmelerine Yönelik Yapılan Etkinlikler Sırasındaki İletişim}

Öğrencilerin akıl yürütme ve ispat yapma becerileri hakkındaki görüşlerini sorduğumuz öğretmenler, genellikle ispat yapmanın zor ve soyut olduğunu, öğrencilerin bunu yaparken zorlandıklarını, bu süreçte özgüven eksikliği yaşadıklarını, önyargılarının olduğunu, ispat yapmayı gereksiz bulduklarını, sıkıldıklarını, ilgisizleştiklerini ve daha çok kısa ispatları tercih ettiklerini belirtmişlerdir. Bazı öğretmenler ispatın neyin nerden geldiğini göstermesi açısından öğrencilerin ilgisini çektiğini ancak uzun ispatların bu ilgiyi kısa sürede dağıtabileceğini belirtmişlerdir. Bu ifadelere ilişkin öğretmen görüşleri şunlardır:

K2: Genelleme yapacak olursak, öğrencilerin yarısı çekinik. Anlamamış gibi de bakan var. Konudan konuya da değişiyor bu durum. İlgisini çeken de var. Çok güzel örneklerle de sinıfin tamamina hakim olabiliyorsun. Soyut bir şey olduğu zamansa uyku pozisyonuna bile geçebiliyor ögrenci. Konudan konuya değişiyor galiba. Ispat çok zor. Soyut bir şey ispat. Neyin nerden geldiği, bana ispat deyince teoremin ispatı gibi geliyor. Ben ispat edelim dediğim zaman öğrenciler: "Hocam bunu yerine bir soru daha çözebilir miyiz? Nasıl olsa bunu birisi bulmuş". Neyin nerden geldiği önemli ama onlara göre bir soru bir sorudur.

K4: Öğrencilerimdeki özgüven eksikliği, ispat yapma becerilerini sinırlıyor. "Öğretmen her şeyi bilir, öğrenci matematiği yapamaz, yapsa da yanlıştır” önyargısı bu noktada karşımıza çıkıyor.

K7: Valla slkaliyor öğrenci. Fen lisesinde bile sıkllyor. Ama onların anlayabileceği türden ispatlar da bu daha çok geometride daha çok oluyor. Bir kosinüs teoremini ispatlyorum "Aa bu muymuş?" diyor. Bir sinüs kosinüs fonksiyonlarının birim çemberde oluştuğunu gördüğ̈̈ zaman bir tanjantın, sinüs kosinüsle benzerlikle ilişkisini kurduğu zaman "bu muymuş?" diyor. Çocuk ezber yapmıs.

K12: İspatı eskiden yapardık. İspattan çok hazır bilgi istiyorlar. Sonucu verin ya da uygulamaya geçelim.

K15: Kısa ispatlar hoşlarına gidiyor ama uzuyorsa onlar için işkence. Nerden neyin geldiğini bilmek isteyen çok az ögrenci var. Onlar da matematiğe ilgi duyan ve başartl ögrenciler zaten.

K1: İspat yöntemlerinin ispatlanabilir olanlarını vermeye çallşlyoruz. "Bu budur, şudur!" deyip geçmiyoruz. Öğrenciler "iyi ki böyle anlattınız aklımızda kalıyor" diyor ama her teoremi de ispatlama gibi bir zamanımız olmayacă̆ için de çok basit ufak tefek teoremlerin ispatların gösteriyoruz. Genelde ögrenciler ispatlardan memnun kaldılar. Çıkış noktasını bilmek aslında ögrrencinin hoşuna gidiyor. Çıkış noktasını gördüğ̈̈ zaman "aa bu oradan gelmiş" daha kalıcl oluyor. 


\subsection{Tercih Edilen Yöntem ve Teknikler}

Öğretmenlere hedeflenen becerileri geliştirmeye yönelik derslerde hangi yöntem ve teknikleri tercih ettiklerini sorduğumuzda, genellikle düz anlatım olmak üzere bunun yanı sıra soru cevap, beyin fırtınası, drama, istasyon tekniği, buluş yöntemi, grup çalışması, problem çözme yöntem ve tekniklerinden faydalandıklarını ifade etmişlerdir.

K1: Genelde soru cevap, düz anlatım. Görsel olarak videoları gösteriyorum. Soru cevap daha çok oluyor.

K3: Hikayeleştirme, oyun, drama gibi etkinlikler yapıyoruz.

K8: Hikayeleştirmek lazım matematiği. Matematiğin bazı gizemli şeyleri vardır. Heyecan uyandirır mesela sonsuzluk bir heyecan uyandirır. Öğrenciye sorarız sonsuz neden sonsuz niye sonsuz? Sonsuz üzeri sonsuz niye 0 değil? Neden 2 üzeri 0 neden 1? 0 saylsı değişik bir sayl. Ne pozitif ne negatif bir şey. Taban aritmetiğinde 2li taban aritmetiğinin bilgisayarda klavyede kullandiğımızda işte "a" harfine bastı̆̆ınızda bunu ikilik tabanda kodlayarak, bir koduna sinyal gönderip sifir koduna sinyal göndermeyip işte taban aritmetiği budur diye ögrenci soruyor "neden taban aritmetiğini kullaniyoruz?”. Bunlartn nerede olduğunu, nasıl kullanılacağını anlatırsanız çocuk daha ilgili oluyor bana.

K10: Genellikle düz anlatım yapıyoruz. Öğrencileri tahtada soru çözmeye teşvik ediyorum. En azından derse katılsınlar, konuya hâkimiyetleri artsın ilgi artsın diye.

\subsection{Tercih Edilen Materyaller}

Öğretmenlere hedeflenen becerileri geliştirmeye yönelik derslerde hangi materyalleri kullandıkları sorulduğunda, 13 öğretmen akı1lı tahtayı yoğun bir şekilde kullandıklarını, 2 öğretmen ise kullanmadığını belirtmiştir. Ayrıca, EBA' da güzel uygulamalar bulunduğunu, konuya göre bazı grafik programlarının kullanıldığı, 3 boyutlu geometrik cisimler için okuldaki materyallerin sıklıkla kullanıldığını belirtmiş̧lerdir.

K3: Başta kullandığımız materyal akıllı tahtamız. Onun dı̧̧ında çocuklara bol bol sorular dağıttıyoruz. Kendilerinin soru yazıp çözmelerini istiyoruz.

K9: Trigonometrinin bir uygulamasını bulmaya çalışlyoruz. Geçen yıllarda "Bermuda şeytan üçgeni" ile ilgili alıştırmalar yaptırmıştım. O bir hayli hoşuma gitmişsti. GPS ile ilgili uygulamalar yaptırdığımı hatırlıyorum. Dünya üzerinde koordinatları belirlerken, sadece enlem ve boylama bakmak yeterli değil. Çok büyük boyutlu arazilerde bu sağlıkl sonuçlar vermeyecek. Bunun için daha alt birimlere ihtiyacımız vardı. GPS ile ilgili böyle bir çalışmamız vardl. Özellikle türev ve integral konularında mühendislik uygulamalarını yaptırmıştım. Matematiksel uygulamada benim kullanmasın bildiğim bir program yok ama geometride var uygulamalar."Geometry Expressions" diye bir program vardl. O da şekillerin, çok boyutlu cisimlerin döndürülmesi ile alakall. Örneğin bir prizma çizdiniz, prizmalara farklı açılardan bakma şansı, bakabiliyordunuz, şekli çevirebiliyordunuz. Döndürülmesi ile alakalı şeyler vardı orada.

K12: Genellikle akıllı tahta kullanıyorum. Yeri geliyor geçmişte yaşanılan matematik ile ilgili anılarımı anlatıyorum.

$\mathrm{Bu}$ konuyla ilgili görsel sanatlar lisesinde çalışan matematik öğretmeni öğrencilerin görsel ve işitsel zekalarının sayısal zekaya göre çok daha gelişmiş olduğunu söyleyerek, derslerde 
görselliğin çok daha ön planda olduğunu ve öğrencilerinin hazırbulunuşluluk seviyelerinin düşük olması sebebiyle çeşitli eğlence oyunlarına başvurduğunu ifade etmiştir.

K1: Akll oyunları verdim mesela geçen dönem. Oradaki oyunlarla ilgili performans ödevleri verdim ve bununla ilgili güzel dönütler aldım. Ne kadar anladıklarını bilmiyorum ama zevk aldıklarını düşünüyorum. Biraz daha kafalarını çalıştırdıklarını düşünüyorum hoşlarına gitti performans. Hem not allyorlar hem de ĕgleniyorlar. Örneğin "tangramı" vermiştim birine, birde "jenga boom" vermiştim. Onu geldik sinıfta oynadık, süre verdik. Onun çok matematiksel olduğunu düşünmediler. Aslında bu matematiksel bir şey, onu ordan çekmek, düşünmek, ağırlık noktasını hesaplamak matematiksel bir şey aslında, hoşlarına gitti. En kötüsü bile "ben de oynayacağım" dedi. Bir de "look look" vardı görsel zekaya bakarlar, yan yana şekiller vardır, üst üste kağıt açılır. Orada küçük şekli bulmaya çalışırsınız. Onu yaptık. O çok hoşlarına gitti. Birkaç tane daha yaptık. Bunları da yaptırmaya devam edeceğim eğlenirken öğrenmeleri için.

\section{Tartışma, Sonuç ve Öneriler}

Kuşkusuz, öğrencilere matematiksel iletişim sağlayabilme, matematiksel akıl yürütme ve ispat yapma, günlük dil ile matematiksel dili ilişkilendirme, tümevarım ve tümdengelim yapma becerilerini kazandırmayı hedefleyen bir öğretim programının bu konuda başarılı olabilmesi için eğitim öğretim sürecinde tüm faktörlerin birlikte işe koşulması gerekmektedir. Araştırmada görüşlerine başvurulan çalışma grubunun verileri analiz edildiğinde, özellikle modelleme uygulamaları olmak üzere birçok becerinin kazandırılma sürecinde öğretmenlerin yetersiz kaldığ 1 ve bu durumu önlemeye ilişkin hizmet-içi eğitim, seminer gibi faaliyetlerde bulunulmaması, öğrencileri sadece hılı soru çözmeye yönlendiren merkezi sınav sisteminin varlığı, mevcut öğretim programını yetiştirmek adına hedeflenen üst düzey düşünme becerilerini kazandırmaya yeterli sürenin ayrilamaması, sınıf mevcutlarının düşürülmemesi, öğrencilerin hazırbulunuşluk düzeylerinin eksikliği gibi problem durumları saptanmıştır. Üstelik bu durumun fen lisesi, Anadolu lisesi, sosyal bilimler ve mesleki teknik anadolu liseleri gibi eğitim düzeyi farklılaşmakta olan okullarda da benzerlik göstermesi büyük bir problemin varlığına işarettir.

Öğretmenlerin "matematiksel modelleme" ile ilgili soruya verdikleri cevaplar incelendiğinde, çoğu öğretmenin akıllı tahta ve tablet aracıllı̆ı ile yapılan etkinliklerden bahsetmesi, "Katılımcılar, bu konu hakkında yeterli bilgiye sahip mi?"sorusunu akla getirmektedir. Bu durumda, matematik öğretmenlerine modellemelerle ilgili seminer ya da hizmet içi eğitim verilmesi yararlı olacaktır. Bir katılımcı "Sadece problem çözme aşamasında bunlarl yapıyoruz. Aslında bizde eğitim almadık bu modellemeler konusunda. Bu konuda matematik ögretmenlerine yönelik hizmetiçi eğitim verilmesi çok önemli aslında." şeklinde bu eğitimin gerekliliğini ifade etmiştir.

Öğretim programının hedeflediği kazanımların geliştirilebilmesi için ve etkinliklerin uygulanabilmesi için gerekli olan araç- gereç ve materyallerin genellikle akıllı tahta ve tablet kullanımı olduğu saptanmıştır. Birçok öğretmenin okullarda katı cisim materyalleri dışında materyal bulunmadığını ve materyal geliştirme konusunda çok yetkin olmadıkları ifadesinden de bu konuda öğretmenlere yönelik eğitim çalışmaları yapılması gerektiği gerçeğini ortaya koymaktadır. Ayrıca EBA' da modelleme etkinliklerine daha fazla yer verilebilir.

Öğretmen görüşlerinden elde edilen sonuçlara göre, yeterlilik ve becerilerin öğretiminde öğretmenin merkezde olduğu ve aktaran rolünü devam ettirdiğine yönelik açıklamalar daha 
fazladır. Soru cevap, beyin firtınası, drama, istasyon tekniği, buluş yöntemi, grup çalıșması, problem çözme gibi yöntem ve teknikleri kullanan öğretmenlerin azınlıkta kaldığ görülmektedir. Bu bağlamda öğretmenlerin öğrenci merkezli yaklaşım ve teknikleri daha fazla tercih etmeleri gerektiği sonucu ortaya çıkmıştır.

Öğretmen görüşleri değerlendirildiğinde, görülen önemli bir eksiklik de öğrencilerin matematiğin günlük hayatla ilişkisini kavrayamamış olduklarıdır. Öğretmenler genellikle, öğrencilerin "bu konuyu günlük hayatta nerede kullanacağız?" tarzında sorular sorduklarından yakınmaktadırlar. Bu duruma sebep olarak yine öğrencilerin daha fazla soru çözmeleriyle doğru orantılı olarak başarılı olacaklarına inanmalarına neden olan sınav sistemi ve bu sınav sisteminin öğrencilerin düşünme yeteneklerini standartlaştırması ve ezberci anlayışa sürüklemesi gösterilebilir. Bu durum, görüşme yaptığımız bir öğretmen tarafından şöyle ifade edilmektedir: "Her konuyu anlattı̆ııda sinıftan gelen şu cümleler artık 'hocam hep bu şekilde mi yapacă̆ız? Hep bunu gördüğümüzde hep böyle mi yapacağız?. Standartlaştırmaya, ezberlemeye çalışıyorlar".

Öğrencilerin matematiği kendi içinde ve farklı disiplinlerde ilişkilendirme başarılarına yönelik olarak öğretmen görüşleri incelendiğinde genel olarak öğrencilerin başarılı bulunduğu belirlenmiştir. Bu duruma örnek vermek isteyen bir öğretmenin görüşleri şu şekildedir: "Örneğin logaritmanın kimya sanayisinde kullanıldığını, çok küçük sayılar olduğunu, işte ne bileyim sinüs kosinüs tanjant kotanjantın fizikte çok fazla kullanıldığını ivmeleri falan hesaplarken kullanıldığını, sürtünme katsayılarını hesaplarken kullanıldı̆̆ını bunları her konu başllğ̆ geldiğinde bir nevi bahsediyoruz."

Öğrencilerin matematiksel modelleri, kuralları ve ilişkileri ne sıklıkta kullandıklarına yönelik öğretmen görüşleri değerlendirildiğinde ise, öğrencilerin bu konuda oldukça yetersiz olduğu anlaşılmaktadır. Bazı öğretmenler ise, bu duruma sebep olarak öğrencilerin hazırbulunuşluk seviyelerinin düşük olmasını göstermektedir.

Matematiksel modelleme uygulamalarının ders kitaplarında ne ölçüde yer aldığıyla ilgili öğretmen görüşleri değerlendirildiğinde ise, öğretmenlerin çoğunluğun belirttiği (9 kişi) "kitaplarda çok zor etkinlikler olduğunu", "içeriğinin zenginleştirilmesi gerektiğini", "örneklemelerin yetersiz kaldığını", "amacına uygun olmayan örneklerin bulunduğu”, "modellemeler yerine soru sayısının fazla olduğu" şeklindeki ifadelerden ders kitaplarının modellemeler anlamında tekrar gözden geçirilmesi ve yapılandırılması gerektiği sonucuna ulaşılmıştır.

Öğretmen adaylarının tümdengelim ve tümevarım konusundaki görüşleri dikkate alındığında, öğrencilerin sıklıkla tümevarım yaptıklarını ve tümdengelim yapabilme becerisine sahip olmadıkları sonucuna ulaşılmıştır. Bu sonuçlara dayanılarak tümdengelim becerisini geliştirecek uygulamaların ve konu anlatımlarının ders kitaplarında daha fazla yer alması sağlanabilir.

Öğrencilerin akıl yürütme ve ispat yapabilme becerilerine ilişkin öğretmen görüşleri incelendiğinde, öğrencilerin genellikle bu konuda oldukça başarısız olduklarını, ispatın zor ve soyut geldiği ve derslerde ispat yapmak yerine soru çözmeyi tercih ettikleri ortaya konmuştur. Bu durum, öğrencilerin cebirsel ifade ve işlemleri kullanarak doğrudan ispat yapabilme becerisinde olmadıklarını, ayrıca öğrencilerin dolaylı yoldan (olmayana ergi yöntemi, çelişki bulma yöntemi) akıl yürüterek, tümdengelimsel muhakeme becerilerini kullanmakta da yetersiz olduklarını ortaya koymuştur. 
Bir katılımcı matematiğin somutlaştırılmasına ve buna bağlı olarak modellemelere karșı olduğunu ifade ederek, araştırmaya çok farklı bir bakış açısı getirmiştir. İlköğretimde matematiğin somutlaştırılması gerektiğini fakat lise döneminde matematik dersinin amacının öğrencilerin düşünme yetisini geliştirmek olduğunu, dersin yapısının somutlaştırmaya müsait olmadığını ve lisede soyut öğrenebilen öğrencinin çok daha başarılı olduğunu belirtmiştir. "Yani kişisel olarak ben somutlaştırmaya karşıyım. Matematiğin ortaya çıkış sebebi soyut olması değil mi? Matematiğin somutlaştırılması bizi bu dersin amacından uzaklaştıracak. Yani soyut ögrrenen çocuklar daha başarılı oluyorlar. Bence soyut ögrenen çocuk somut öğrenen çocuklara göre daha başarılı oluyor. Soyut ögrenen çocuk yorum yapabiliyor" şeklinde ifade etmiştir. Bu ifade başlı başına bir araştırma konusu olarak ele alınabilir. 


\section{KAYNAKÇA}

ACAR, E. (2013). İlköğretim Düzeyinde Matematik Yeterliliği İçin Gerekli Dört Temel Prensipten Birisi "Tersine Çevirme Prensibi" Nedir? Neden Önemlidir? Stratejileri Nelerdir?. Balıkesir Üniversitesi Sosyal Bilimler Enstitüsü Dergisi. Cilt: 16, Sayı: 30.

ALTIPARMAK, K. ve ÖZİ̧, T. (2005). Matematiksel İspat ve Matematiksel Muhakemenin Gelişimi Üzerine Bir İnceleme. Ege Ĕgitim Dergisi, 1(6), 25-37.

ALTUN, M. (2002). İlkögretim İkinci Kademede (6, 7 ve 8. Siniflarda) Matematik Ögretimi. Bursa: Erkam Matbaası.

ARSLAN, S. ve YILDIZ, C. (2010). 11. Sınıf Öğrencilerinin Matematiksel Düşünmenin Aşamalarındaki Yaşantılarından Yansımalar. Eğitim ve Bilim Dergisi, Cilt 35, Sayı 156.

BULUT, S. , KIRMACI, U. , ÖZTURAN, S.M. (2010). Türev Konusunda Uygulanan Matematiksel Modelleme Yönteminin Ortaöğretim Öğrencilerinin Akademik Başarılarına ve Öz-düzenleme Becerilerine Etkisi. EÜFBED - Fen Bilimleri Enstitüsü Dergisi, 3 (2).

ÇİLTAŞ, A. (2011). Dizi ve Seriler Konusunun Matematiksel Modelleme Yoluyla Ögretiminin İlkögretim Matematik Öğretmeni Adaylarının Öğrenme ve Modelleme Becerileri Üzerine Etkisi. Yayınlanmış Doktora Tezi. Atatürk Üniversitesi Eğitim Bilimleri Enstitüsü.

ÇİLTAŞ, A ve YILMAZ, K. (2013). İlköğretim Matematik Öğretmeni Adaylarının Teoremlerin İfadeleri İçin Kurmuş Oldukları Matematiksel Modeller. Eğitim ve Öğretim Araştırmaları Dergisi, 2(2).

DENIZ, D. (2014). Ortaöğretim Matematik Öğretmenlerinin Matematiksel Modelleme Yöntemine Uygun Etkinlik Oluşturabilme ve Uygulayabilme Yeterlikleri, Yayınlanmış Doktora Tezi. Atatürk Üniversitesi Eğitim Bilimleri Enstitüsü, Erzurum.

DORUK, B. K. (2010). Matematiği Günlük Yaşama Transfer Etmede Matematiksel Modellemenin Etkisi. Yayınlanmış Doktora Tezi. Hacettepe Üniversitesi Sosyal Bilimler Enstitüsü, Ankara.

HATCH, J. A. (2002). Doing Qualitative Research in Education Settings, State University of New York Press.

MEB. (2013). Ortaöğretim Matematik (9, 10, 11 ve 12. sinıflar) Dersi Öğretim Programı. Talim ve Terbiye Kurulu Başkanlığı, Ankara.

OKUR, M. , BAHAR, H. H. , AKGÜN, L. , BEKDEMIR, M. (2011). Matematik Bölümü Öğrencilerinin Öğrenme Stilleri ile Sürekli Kaygı ve Akademik Başarı Durumları. Türkiye Sosyal Araştırma Dergisi, 15(3), 123-134.

OLKUN, S. ve TOLUK, Z. (2003). İlköğretimde Etkinlik Temelli Matematik Öğretimi. Ankara: Anı Yayıncilık.

ÖZGEN, K. (2013). Problem Çözme Bağlamında Matematiksel İlişkilendirme Becerisi: Öğretmen Adayları Örneği. NWSA-Education Sciences, 1C0590, 8, (3), 323-345.

SOYLU, C ve SOYLU, Y. (2006). Matematik Derslerinde Başarıya Giden Yolda Problem Çözmenin Rolü. İnönü Üniversitesi Ĕgitim Fakültesi Dergisi, 7(11).

TAŞTEPE, M. (2012). İspat Kavramının Kitap, Öğretmen ve Öğrenci Boyutunda Incelenmesi. Yayınlanmış Yüksek Lisans Tezi. Marmara Üniversitesi Eğitim Bilimleri Enstitüsü, İstanbul.

TEMIZÖZ, Y. (2013). İlkögrretim ve Ortä̈gretim Öğrencilerinin Matematiksel Problem Çözme Sürecinde Kavramlar Ile İlgili Anlayışlarının ve Kavram-işlem 
Kullanımlarının Rolü. Yayınlanmış Doktora Tezi. Gazi Üniversitesi Eğitim Bilimleri Enstitüsü, Ankara.

The Consortium for Foundation Mathematics, (2008). Mathematical Models with Applications, Texas Edition, Boston, 67-70.

TOPTAŞ, V. (2015). Matematiksel Dile Genel Bir Bakış. International Journal of New Trends in Arts, Sports \&ScienceEducation - 2015, Volume 4, İssue 1: 18-22.

UMAY, A. (2011). Eski Arkadaşımız Okul Matematiğinin Yeni Yüzü. Illkögretim Online, 10(1), $k: 1-3,2011$.

YILDIRIM, A. ve Şimşek, H. (2013). Sosyal Bilimlerde Nitel Araştırma Yöntemleri. 9.Genişletilmiş Baskı. Ankara: Seçkin Yayıncılık.

YILMAZ, K. (2015). Matematiksel Modellerle Teorem İspatlarının İlköğretim Matematik Öğretmenliği Öğrencilerinin İspat Yapabilme Becerilerine, İspatla İlgili Görüşlerine ve Akademik Başarılarına Etkisi. Yayınlanmış Yüksek Lisans Tezi. Atatürk Üniversitesi Eğitim Bilimleri Enstitüsü, Erzurum.

ZAİMOĞLU, Ş. (2012). 8.Sınıf Öğrencilerinin Geometrik Ispat Süreci ve Eğilimleri. Yayınlanmış Yüksek Lisans Tezi. Kastamonu Üniversitesi Fen Bilimleri Enstitüsü, Kastamonu. 